\title{
Intra-testicular signals regulate germ cell progression and production of qualitatively mature spermatozoa in vertebrates
}

\section{Rosaria Meccariello ${ }^{1}$, Rosanna Chianese ${ }^{2}$, Teresa Chioccarelli ${ }^{2}$, Vincenza Ciaramella ${ }^{2}$, Silvia Fasano ${ }^{2}$, Riccardo Pierantoni ${ }^{2 *}$ and Gilda Cobellis ${ }^{2}$}

Dipartimento di Scienze Motorie e del Benessere, Università di Napoli Parthenope, Naples, Italy

2 Dipartimento di Medicina Sperimentale sez "F. Bottazzi," Seconda Università degli Studi di Napoli, Naples, Italy

Edited by:

Joaquin Gutierrez, Universitat de

Barcelona, Spain

Reviewed by:

Gregoy Y. Bedecarrats, University of Guelph, Canada

Anna Di Cosmo, University of Naples

Federico II, Italy

\section{*Correspondence.}

Riccardo Pierantoni, Dipartimento di

Medicina Sperimentale sez

"F. Bottazzi", Seconda Università degli

Studi di Napoli, Via Costantinopoli 16,

Naples 80138, Italy

e-mail: riccardo.pierantoni@unina2.it
Spermatogenesis, a highly conserved process in vertebrates, is mainly under the hypothalamic-pituitary control, being regulated by the secretion of pituitary gonadotropins, follicle stimulating hormone, and luteinizing hormone, in response to stimulation exerted by gonadotropin releasing hormone from hypothalamic neurons. At testicular level, gonadotropins bind specific receptors located on the somatic cells regulating the production of steroids and factors necessary to ensure a correct spermatogenesis. Indeed, besides the endocrine route, a complex network of cell-to-cell communications regulates germ cell progression, and a combination of endocrine and intra-gonadal signals sustains the production of high quality mature spermatozoa. In this review, we focus on the recent advances in the area of the intra-gonadal signals supporting sperm development.

Keywords: testis, spermatogenesis, GnRH, kisspeptins, estrogens, sperm quality, spermatozoa

\section{INTRODUCTION}

In vertebrates, spermatogenesis is a hormonally controlled mechanism charged to produce gametes useful for reproduction. The production of high standard quality gametes is the main goal to preserve reproduction.

Spermatogenesis develops as a process consisting of mitotic, meiotic, and differentiation steps promoting germ cell progression from spermatogonia-to-spermatozoa (SPZ). In male, the hypothalamus-pituitary-gonadal axis supports germ cell progression, via gonadotropin releasing hormone (GnRH)gonadotropin-steroid production and its activity is finely regulated by positive and negative feedbacks. Furthermore, a network of intra-gonadal factors, organized in a complex stage-specific multi-factorial net, is responsible for spermatogenesis control (1).

Using a comparative approach, this review summarizes the intriguing and sometimes conflicting information about the intratesticular role played by GnRH, Kisspeptin, and estrogens in germ cell progression and production of high standard quality sperm.

\section{GnRH, A HISTORICAL MODULATOR OF TESTIS PHYSIOLOGY}

The GnRH, crucial player of the neural control of vertebrate reproduction, was originally isolated from the hypothalamus of pig and sheep (2). Basically, GnRH stimulates the synthesis and the discharge of pituitary gonadotropins [follicle stimulating hormone and luteinizing hormone (FSH and $\mathrm{LH}$ ), respectively], which in turn induce both gametogenesis and the production of gonadal steroids. At present, $25 \mathrm{GnRH}$ forms have been identified in protochordates and vertebrates $(3,4)$ and in many vertebrates three $\mathrm{GnRH}$ molecular forms have been identified: GnRH-1, GnRH-2, and GnRH-3 (formerly known as mammalian,
chicken-II, and salmon GnRH, respectively) (3). GnRH action is mediated through high-affinity binding with the GnRH receptor (GnRH-R) $(5,6)$, a rhodopsin-like seven trans-membrane $\mathrm{G}$ protein-coupled receptor (GPCR). In vertebrates, GnRH-Rs exhibit a wide range of subtypes and alternate splicing derived forms $(1,3,5-7)$. The presence of multiple forms of GnRHs and GnRH-Rs in the brain, with specific expression profiles, suggests the existence of different functional roles: in fact, $\mathrm{GnRH}-1$ is considered the final regulator of the pituitary-gonadal axis; GnRH-2 is supposed to play a function for the control of sexual behavior, food intake, energy balance, stress, and many other environmental cues; GnRH-3, found only in the telencephalon of teleost fish, probably acts as neuro-modulator $(1,3,8)$.

Extrahypothalamic synthesis and function of GnRHs and GnRH-Rs have been detected in many reproductive tissues in vertebrates, including human (gonads, prostate, endometrial tissue, oviduct, placenta), and in cancer cells (1, 5, 9-11).

$\mathrm{GnRH}$ plays several conserved roles in testis physiology, being the main paracrine modulator of the Leydig-Sertoli, Sertoligerm cell, Sertoli-peritubular cell communications $(1,12)$. In this context, it drives steroidogenesis, germ cells progression, and acquisition of SPZ functions $(1,12-15)$.

The demonstration of a direct GnRH effect on testis has been provided in fish, frog, rodent, and human Leydig cells showing GnRH-specific high-affinity binding sites $(1,3,15,16)$. The finding of GnRH mRNA in Sertoli and spermatogenic cells in different species (17) suggests its involvement in paracrine Leydig-Sertoli cell communication (12). A similar pattern of expression has been confirmed in human (17), expressing two GnRH molecular forms and two GnRH-Rs $(18,19)$. However, the identification 
of GnRH-R2 antisense transcript in human testis (20) and the presence of frame-shift mutations and stop codons in human $G n R H-R 2$ (5) may indicate that these transcripts are not really functional.

The major reported effect of GnRH on vertebrate testis physiology concerns the modulation of steroidogenesis in in vivo and in vitro systems (1, 21-23). Interestingly, in elasmobranch and in dipnoi, this effect appears to be exerted trough the endocrine route $(24,25)$. Both GnRH-1 and GnRH-2 agonists have the ability to stimulate mouse pre-pubertal Leydig cell steroidogenesis, in a dose- and time-dependent manner, via transcriptional activation of $3 \beta$-hydroxy-steroid dehydrogenase (3 $\beta$-HSD) (23). Accordingly, in human, the expression levels of GnRH-1, GnRH-2, GnRH-Rs, cytochrome P450 side-chain cleav-

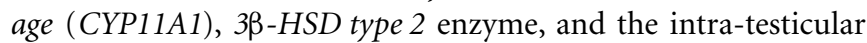
testosterone $(\mathrm{T})$ levels are significantly increased in patients with spermatogenic failure (26). At molecular level, the transduction pathway involving the $\mathrm{GnRH}$ agonist-dependent activation of ERK1/2 has been reported (27). Interestingly, in mouse testis, GnRH-R activity well correlates with the increased steroidogenic activity observed during pubertal and adult stages and its decline parallels the decreased steroidogenic activity observed during the senescence (28). These expression profiles are consistent with the increasing expression of the gonadotropin inhibitory hormone $(\mathrm{GnIH})$ during senescence, providing evidences of local interaction between GnRH and GnIH. The testicular localization of GnIH and its receptor GPR147, in both mammals and birds, opens new perspectives in the autocrine/paracrine control of testicular activity suggesting a possible interplay between $\mathrm{GnRH}$ and $\mathrm{GnIH}$ in order to modulate $\mathrm{T}$ secretion and spermatogenesis (29). Furthermore, GnRH activity in Leydig cells is not restricted to $\mathrm{T}$ production but is extended to the development of rat progenitor Leydig cells both in vivo and in vitro (30).

Several studies, carried out in cancer cell lines, demonstrated a direct anti-proliferative/apoptotic effect of $\mathrm{GnRH}$ and its synthetic agonists $(31,32)$. Accordingly, GnRH activity is a well-known modulator of germ cell apoptosis during the regression of fish gonad $(33,34)$. In rodents, GnRH agonists stimulate spermatogenic colony formation following spermatogonia (SPG) transplantation $(35,36)$ and induce SPG proliferation in damaged testis (37). In mollusk, a scallop GnRH-like peptide stimulates SPG cell division (38). In amphibian, a GnRH agonist induces G1-S transition of SPG cell cycle (39-43) whereas, in mouse, GnRH is expressed in gonocytes at birth (28). At molecular level, in the anuran amphibian Rana esculenta, SPG proliferation requires the cooperation between estradiol $\left(\mathrm{E}_{2}\right)$ and $\mathrm{GnRH}$, in a mechanism involving the $\mathrm{E}_{2}$-dependent transcriptional activation of $c$-fos (42) and a GnRH-mediated translocation of FOS protein from the SPG cytoplasm into the nucleus (43). Thus, GnRH activity may represent a key controller of proliferative/anti-proliferative events characteristic of testis renewal. Consistently, it has been found that $\mathrm{GnRH}$ induces proliferation of partially differentiated gonadotrope cells (44).

Lastly, the ability of GnRH agonists to induce spermiation (45) and the localization of GnRH and/or GnRH-Rs in spermatids (SPTs) and SPZ in mammalian and non-mammalian vertebrates $(17,28,46,47)$ suggest the involvement of $\mathrm{GnRH}$ signaling in
SPZ functions and fertilization. Accordingly, GnRH antagonists inhibit, in vivo and in vitro, fertilization in rodents (14) whereas sperm binding to the human zona pellucida and calcium influx in response to GnRH and progesterone have been reported (13), providing evidence of functional role of GnRH-Rs in human SPZ.

The above indicated intra-testicular activity of GnRH has been described in detail in the frog R. esculenta, a species showing a complex GnRH system, deeply characterized at testicular level (46). In this seasonal breeder, two GnRH molecular forms (GnRH-1 and GnRH-2) and three receptor forms (GnRH-R1, -R2, -R3) (48) with specific expression pattern and localization in testis during the annual reproductive cycle (46) have been identified. In situ hybridization suggests a different role for $G n R H-1$ and $G n R H-2$, as $G n R H-1$ and $G n R H-R 1$ seem to be linked to germ cell progression and interstitial compartment activity, whereas GnRH-2 and $G n R H-R 2$ seem to be linked to sperm function and release (46), confirming the hypothesis that each ligand might be involved in the modulation of specific processes. Interestingly, this functional portioning well correlates with the differential modulation of GnRH system counterparts exerted via the activation of endocannabinoid system, an evolutionarily conserved system deeply involved in central and local control of reproductive functions (49-52). At central level, in mammals, endocannabinoids interfere with $\mathrm{GnRH}$ production $(53,54)$ and signaling $(55)$. In frog diencephalons, they modulate the expression of $G n R H-1 / G n R H-2$ $(48,56,57)$ - both hypophysiotropic factors (1), GnRH-R1 and GnRH-R2 (48) (Figure 1). Furthermore, in frog testis, the endocannabinoid anandamide (AEA), via type 1 cannabinoid receptor (CB1) activation, modulates testicular GnRH activity at multiple levels and in a stage-dependent manner (46) (Figure 2). Interestingly, the activation of cannabinoid receptors other than CB1, such as the vanilloid transient receptor type 1 (TRPV1), differentially modulates the expression level of $G n R H s / G n R H-R s$, but in an opposite manner as compared with CB1 (58). Thus, the transcriptional switch on/off of testicular GnRH system is finely toned through the activation of specific endocannabinoid receptors, providing evidence of a central role of this system in the local modulation of GnRH activity.

\section{KISSPEPTINS, POSSIBLE PLAYERS IN TESTIS PHYSIOLOGY CURRENTLY UNDER INVESTIGATION}

Kisspeptins are a novel class of neuro-peptides with a key position in the scenario of reproduction. They are encoded by the kiss 1 gene, originally discovered as a metastasis-suppressor gene in 1996 (59), and they are initially produced as an unstable 145-amino acid precursor peptide (kp145), then cleaved into shorter peptides (kp-54, kp14, kp-13, and kp-10). Interestingly, all kisspeptin shorter peptides are biologically active due to the binding to the "kiss" receptor GPR54 (60). The primary targets of kisspeptins are just the hypothalamic GnRH-secreting neurons (61) and, similarly to the deletion/mutation of $G n R H$ or $G n R H-R$ genes, target disruption of both kiss1 and GPR54 leads to hypogonadotropic hypogonadism and lack of sexual maturation $(62,63)$. Accordingly, the administration of kisspeptins accelerates the timing of puberty onset in fish (64-67) and mammals $(68,69)$, whereas circulating higher kisspeptin levels have been observed in clinical cases of precocious puberty in human $(70,71)$. 
Several studies have been focused on the characterization of the kisspeptin-dependent signaling in the hypothalamus, with particular concern to the negative and the positive feedback action of sex steroids on kiss 1 gene expression in the arcuate and the anteroventral-preoptic nucleus, respectively [for review see Ref. (72)]. Therefore, in the last years, the idea that kisspeptin signaling is an essential guardian angel of reproduction, through the regulation of GnRH neurons, took place. These views strongly stride with evidences that genetic ablation of nearly all kisspeptin neurons does not impair reproduction, suggesting that possible compensatory

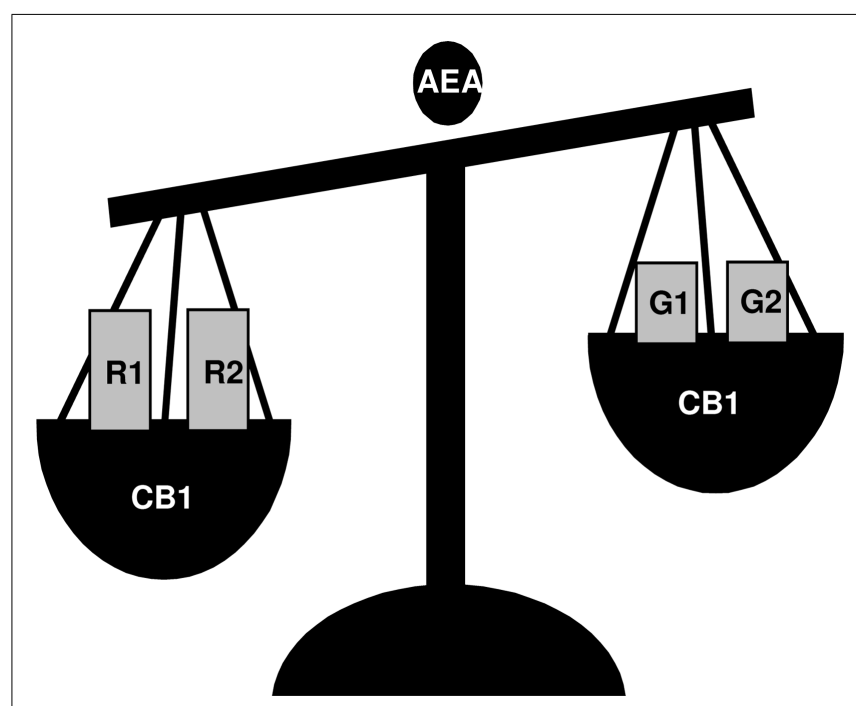

FIGURE 1 | A schematic view of the effects of AEA incubation on GnRH-1 (G1), GnRH-2 (G2), GnRH-R1 (R1), and GnRH-R2 (R2) expression in frog $\boldsymbol{R}$. esculenta diencephalon. Animals were collected in June and testes were incubated in vitro for $1 \mathrm{~h}$. Via CB1 activation, AEA treatment significantly increased the expression of $G n R H-R 1$ and $G n R H-R 2$ whereas it decreased the expression of both $\mathrm{GnRH}-1$ and $\mathrm{GnRH}-2$; no effect on $G n R H-R 3$ was observed.

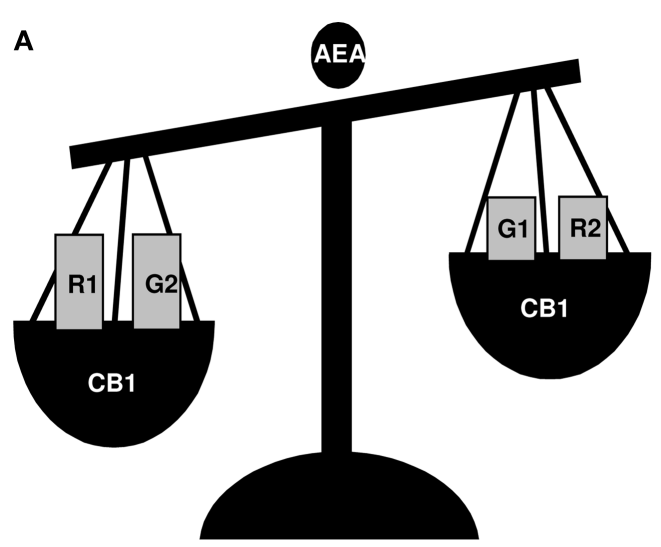

FIGURE 2 | A schematic view of the effects of AEA treatment on GnRH-1 (G1), GnRH-2 (G2), GnRH-R1 (R1), GnRH-R2 (R2), and GnRH-R3 (R3) expression in frog $R$. esculenta testis. Animals were collected in June (A) and February (B) and testes were incubated in vitro for $1 \mathrm{~h}$. In June, AEA treatment significantly increased the expression of mechanisms rescue reproduction (73). Probably, kisspeptin neurons and related products are in excess of what is really required to support reproductive functions. In this respect, male and female mice with a 95\% reduction in kiss1 transcript levels are normal and sub-fertile, respectively. This suggests that an overproduction of kisspeptin represents a failsafe to guarantee reproductive success (74).

A novel chapter of kisspeptin saga concerns the possible intragonadal action of these molecules. Kiss1 and/or GPR54 have been observed in several peripheral tissues, gonads included. In particular, the presence of both ligand and receptor has been observed in the human placenta $(75)$ and testis $(60,75)$ whereas GPR54 alone has been detected in mouse (76), rat (77), rhesus monkey $(78,79)$, and frog $(80)$ testis. However, the functional mechanisms of kisspeptin/GPR54 system in gonads remain to be elucidated and several conflicting data concerning the direct involvement of kisspeptin activity in testis physiology emerged.

Long term kisspeptin-10 (kp-10) (81) and/or kp-54 (82) administration in maturing and adult rat testes gives rise to degenerative effects on spermatogenesis and suppresses the circulating levels of LH and T; no effects have been registered upon FSH levels. Specifically, germ cell number significantly decreases, many germ cells appear regressed, atrophied, and in necrosis; round and elongated SPTs show abnormal acrosome; intraepithelial vacuolization is visible, interstitial spaces are enlarged, and the germinal epithelium is irregularly shaped. Leydig cells frequently lose contacts with the seminiferous tubules and Sertoli-germ cell interaction is destroyed (81). A similar degenerative effect - caused by continuous administration of $\mathrm{kp}-10$ - has also been discovered in rat seminal vesicles (83) and pre-pubertal prostate gland (84). Conversely, a physiological role of kisspeptins in testis has been completely excluded in mouse (85) and conflicting data concerning the localization of kiss1/GPR54 protein and mRNA recently emerged. The use of different antisera, strategies, and strains as well might be taken in account to explain these discrepancies and the missing overlapping in mRNA/protein detection described

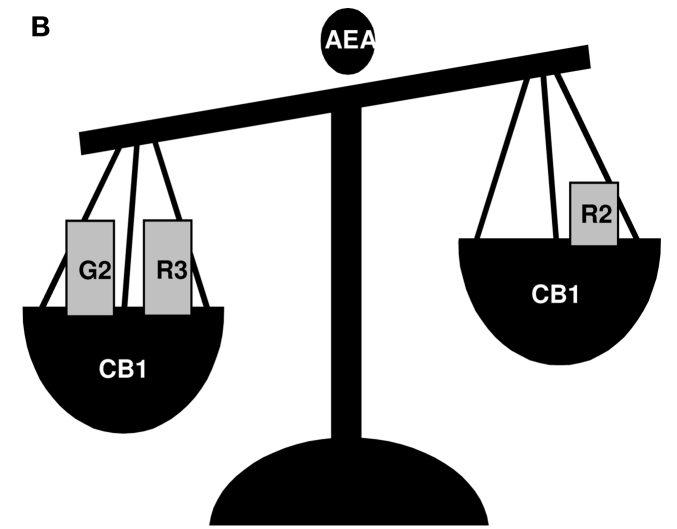

$\mathrm{GnRH}-\mathrm{R} 1$ and $\mathrm{GnRH}-2$ whereas it decreased those of $\mathrm{GnRH}-1$ and $G n R H-R 2$, and had no effect on $G n R H-R 3$; in February, AEA treatment increased $G n R H-2$ and $G n R H-R 3$ expression, decreased $G n R H-R 2$, and had no effect on $\mathrm{G} n \mathrm{RH}-1$ or $\mathrm{GnRH}-\mathrm{R} 1$. In both periods, AEA-dependent effects occurred via CB1 activation. 
so far. In fact, in transgenic mice with LacZ targeted to either kiss1 or GPR54 genes, kiss1 and GPR54 mRNA have been localized in mouse round SPTs, whereas kisspeptin protein has been shown in Leydig cells, with no staining in SPTs (85). Conversely, both GPR54 and kiss1 immunoreactivity has been provided in both Leydig and germ cells (primordial germ cells and elongating SPTs) with significant age-related variations (28). Studies conducted in Leydig cell line MA-10 - a cell line that expresses $\mathrm{LH}$ receptors and responds to human chorionic gonadotropin (hCG) stimulation, producing progesterone as major steroid hormone - confirm that these cells produced GPR54 mRNA, but were unable to show any kiss1 expression (85). Despite GPR54 expression, from a functional point of view $\mathrm{kp}-10$ does not exert any significant direct effects on steroid production in both MA-10 cell line or in physiological systems, such as mouse seminiferous tubule explants (85). However, evidences reported in other species examined so far, pointed out a possible role of kisspeptin system just in steroidogenetic activity. Although Leydig cells do not show any kisspeptin and/or GPR54 immuno-localization in rhesus monkey (78), intra-testicular action on steroidogenesis (79) has been demonstrated in monkeys treated with acyline, a GnRH-R antagonist (86), just to exclusively investigate kisspeptin activity without any influence of pituitary gonadotropic drive. In these clamped monkeys, kp-10 has a synergic effect with hCG to induce T production (79). Anyway, the real possible mechanism through which kisspeptin enhances $\mathrm{T}$ production in primates is not clear and may require additional paracrine routes involved in Leydig-Sertoli cell communications. In fact, in rhesus monkey kisspeptin immunoreactivity has been detected in spermatocytes (SPCs) and SPTs, whereas GPR54 has been localized in SPCs and Sertoli cells (78). Thus kisspeptin - produced by germ cells - might act in an autocrine/paracrine manner to control the progression of the spermatogenesis and/or to modulate Sertoli cells activity. It is noteworthy, however, that intravenous injection of the kisspeptin antagonist 234 (kp-234) (87) does not alter plasma T levels in adult rhesus monkey. Interestingly, Anjum and co-workers reported that kisspeptin expression - analyzed by slot blot analysis in Leydig cells of Parkes strain mice - significantly decreases from birth to pre-pubertal testis, increases during pubertal period, decreases in reproductive active mouse to further increase during the senescence. These expression profiles well correlate to $\mathrm{GnIH}$ expression and to the decreased steroidogenic activity observed during the senescence, providing evidence of a possible involvement of kisspeptin in the control of steroidogenesis in cooperation with testicular GnIH (28).

The detection of kiss 1 and GPR54 mRNA in round/elongating SPTs $(28,78,85)$ raises the possibility that autocrine or paracrine kisspeptin actions might be involved in spermiogenesis and in the acquisition of sperm functions, as recently demonstrated in human SPZ by Candenas and co-workers (88). This group immunolocalized kisspeptin and GPR54 in the post-acrosome region of the human SPZ head and in the equatorial segment of the tail, providing also evidence of some regulatory actions. In fact, $1 \mu \mathrm{M} \mathrm{kp}-13$ increases $\left[\mathrm{Ca}^{2+}\right]_{\mathrm{i}}$ and induces a small, but significant change in sperm motility, leading to motility trajectories that characterize hyper-activated SPZ. Instead, the same treatment has no effect on acrosome reaction (88). Very recently, in mouse, GPR54 has been specifically localized in the acrosomal region of SPTs and mature SPZ whereas kisspeptin expression has been detected in the cumulus-oocyte complex and oviductal epithelium of ovarian and oviductal tissue (89). Since SPZ treatment with $\mathrm{kp}-234$ decreases the in vitro fertilization rates, evidence emerged that kisspeptin modulates fertilization capability in mammals (89).

Interestingly, in sexually immature scombroid fish, kp-15 peripheral administration induced spermiation (67), accordingly to GPR54 expression detected in the myoid peritubular cells in amphibians (80), indicating a possible involvement in sperm transport and release.

Compelling evidence about gonadal activity of kisspeptin system recently comes from a non-mammalian vertebrate, the anuran amphibian, the frog $R$. esculenta. In this seasonal breeder, germ cell progression is under the control of endocrine, environmental, and gonadal factors $(90,91)$, whereas spermatogenesis proceeds in cysts, typical formations consisting of Sertoli cells enveloping cluster of germ cells at a synchronous stage (91). During the frog annual sexual cycle, GPR54 mRNA has been analyzed in testis, showing higher expression at the end of the winter stasis and during the breeding season (80). In these periods, in an $\mathrm{E}_{2}$-dependent fashion, the recruitment of SPG and the onset of a new spermatogenetic wave take place $(42,91,92)$. Consistently, in February, GPR54 mRNA has been revealed in primary and secondary SPG by in situ hybridization (Figure 3) (80) accordingly to kisspeptin localization in primordial germ cells observed in mouse (28). In proliferating germ cells, a strong expression of GPR54 mRNA has been found in interstitial compartment of frog testis all over the annual sexual cycle (Figure 3). Contrary to human, in frog post meiotic cells and SPZ do not express GPR54 mRNA, but it is not excluded that the GPR54 mRNA produced in SPG might be translated in later stages. Since $E_{2}$ is likely to be involved in various aspects of testicular activity such as steroidogenesis and primary SPG proliferation (42, 93-95), a possible relationship between $\mathrm{E}_{2}$ and kisspeptin/GPR54 has been analyzed in frogs. In this respect, an $\mathrm{E}_{2}$-dependent modulation of GPR54 expression has been reported in testis. In addition, kp10 , in vitro, is able to modulate both GPR54 and ER $\alpha$ expression at the end of the winter stasis (February) as well as during the breeding season (March) (80). Therefore, via kisspeptins/GPR54 activation, $\mathrm{E}_{2}$ might regulate steroidogenic activity and SPG proliferation. This hypothesis is supported by the localization of GPR54 mRNA that well correlates with the sites of $E_{2}$ action occurring in frog testis (90). Thus, the expression of GPR54 inside the interstitium and in proliferating SPG, as well as its $\mathrm{E}_{2}$-dependent expression, strongly support the hypothesis that kisspeptin might have a direct involvement in the onset of the spermatogenetic wave. Accordingly, subcutaneous administration of $\mathrm{kp}-15$ accelerates spermatogenesis in the pre-pubertal teleost Scomber japonicus without any significant change in the expression of hypothalamic $G n R H-1$ and pituitary $F S H \beta$ and $L H \beta$ subunits (66). In addition, kp-10 involvement in differentiation events has been further confirmed in the rhesus monkey derived stem cell line r366.4 (96).

It is evident that the several controversies regarding the "kisspeptin saga" make their history more intriguing with many "behind-the-scenes" yet to be written. 

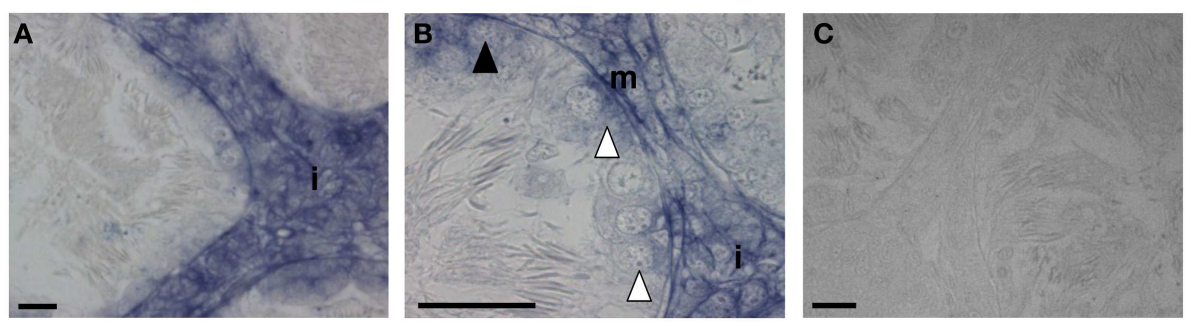

FIGURE 3 | Sections of $\boldsymbol{R}$. esculenta testis, collected in February, analyzed by in situ hybridization for GPR54. GPR54 mRNA was detected in the interstitial compartment $(\mathbf{A}, \mathbf{B})$, in primary spermatogonia (B), in secondary spermatogonia cysts (B) as well as in myoid peritubular cells (B). The specificity of signals was tested through the reaction with a sense riboprobe (C). i, Interstitial compartment; white arrow head, ISPG; dark arrow head, IISPG; m, myoid peritubular cells; scale bar: $20 \mu \mathrm{m}$.

\section{ESTROGENS AND SPERM QUALITY}

Traditionally, $\mathrm{E}_{2}$ is stereotyped as the "female" and $\mathrm{T}$ as the "male" hormone. $\mathrm{E}_{2}$ and $\mathrm{T}$ are instead present in both males and females, and in male the ratio between the two hormones controls reproduction via specific receptors (16). To date, nuclear (ER $\alpha$ and $\operatorname{ER} \beta$ ) and membrane-bound (GPR30) receptors, able to respond to $\mathrm{E}_{2}$ via genomic and non-genomic pathways, respectively, have been identified [for review see Ref. $(97,98)$ ].

Estrogens are synthesized via the irreversible transformation of androgens by the aromatase (P450arom; Cyp19A1 is the related gene), an enzyme expressed in the endoplasmic reticulum of testicular cells. In male, $\mathrm{E}_{2}$ is indeed primarily synthesized in the testis, which expresses also the specific receptors, ER $\alpha$ and ER $\beta$ (16). Recently, GPR30 has been studied in fish, rat, and human and localized in somatic (rat and human) and germ (fish and rat) cells (99-102).

P450arom and ERs expression has been studied in mammalian and non-mammalian testis and the specific mRNA and/or proteins localized in the interstitial (Leydig cells) and tubular (Sertoli and germ cells) compartments, depending on the species [for reviews see Ref. $(1,16,97,103)]$, demonstrating that both somatic and germ cells are able to produce $\mathrm{E}_{2}$ that can act locally.

In vertebrates, $E_{2}$ acts at both central (hypothalamus and hypophysis) $(55,104)$ and local (testis, efferent ductules, and epididymis) $(1,105,106)$ levels and studies in mammalian and non-mammalian species show that $\mathrm{E}_{2}$ regulates proliferation (gonocytes, SPG, Leydig cells), apoptosis (pachytene SPC, Sertoli cells), and differentiation (SPTs) of germ and somatic cells, as well as it regulates spermiation, transport and motility of SPZ, epididymal sperm maturation, and scrotal testicular descent (42, $43,80,97,107-116)$. Some of these functions are evolutionarily conserved from fish to mammals demonstrating that $E_{2}$ plays an important role in male reproduction physiology in vertebrates (1, 90, 117). Expression profiling of spermatogenesis in the rainbow trout identifies evolutionarily conserved genes involved in male gonadal maturation (118). Accordingly, $\mathrm{E}_{2}$-responsive genes have been characterized in gonads enriched of SPG or in isolated germ cells: in both frog $(42,108)$ and fish $(118,119)$, some of these genes are associated to proliferation.

To date, although tissue and cell culture experiments show that $\mathrm{E}_{2}$ may act on germ cells, its direct effect in in vivo systems has not yet been fully elucidated. However, data obtained in mouse, rat, and human models clearly show that $\mathrm{E}_{2}$ is important to produce and sustain high standard quality mature SPZ. Two main observations suggest that $\mathrm{E}_{2}$ is able to act locally into the testis: (1) germ cells express both P450arom and ER, in particular SPTs (120) produce $E_{2}$ that may act via specific receptors (121); (2) Sertoli cell barrier envelops the germinal epithelium, from SPCs to SPTs/SPZ, ensuring a specific micro-environment that allows a correct germ cell progression.

In mouse, P450arom activity is high in germ cells and in particular in SPTs, while is lowered in the interstitial compartment (120). Among germ cells, mainly SPTs and SPZ are responsive to inhibition/inactivation of P450arom and to low $\mathrm{E}_{2}$ levels. Early studies, demonstrated that when rat $(122,123)$ or bonnet monkey (115) were treated with aromatase inhibitors, degeneration of round SPT and a massive decrease of elongated SPTs was found. Later, D'Souza showed that round SPT differentiation (steps 1-6) was largely dependent on $\mathrm{E}_{2}$, whereas SPT elongation (steps 819) was androgen dependent (124). Indeed, high intra-testicular $\mathrm{E}_{2}$ levels preserve round SPTs (steps 1-6) whereas T deficiency, induced by $\mathrm{E}_{2}$, originate pyknotic bodies in elongated/condensed SPTs (steps 8-19) (124). Consistently, loss of $E_{2}$ in human testis promotes apoptosis of round SPTs with loss of elongated SPTs (125) and viable SPZ (126). Therefore, $\mathrm{E}_{2}$ is now considered as a survival factor for SPTs and SPZ.

The bulk of information about the role of $E_{2}$ in germ cell differentiation, from SPT-to-SPZ, came from studies on mutant mice such as the hypogonadic ( $h p g$ ), the Cyp19A1 knock-out (ArKO), and the $C b 1$ knock-out $\left(C b 1^{-1-}\right)(55,127,128)$.

Due to a natural $G n R H$ gene deletion, the $h p g$ mice are functionally deficient in gonadotropins and sex steroids and show meiosis arrest at pachytene stage. Treatment with $\mathrm{E}_{2}$ or ER $\alpha$ agonists restored meiosis in these animals which, in absence of $\mathrm{T}$, produce haploid elongated SPTs (129). The $\mathrm{E}_{2}$ treatment alone was as effective as FSH alone and the combination of both hormones did not produce a greater effect (130). Authors concluded that $\mathrm{E}_{2}$ likely acts on $h p g$ testis via a mechanism involving a weak neuroendocrine activation of FSH secretion (128-130).

The phenotype of ArKO mice and experimental analysis carried out using this mutant mice counteract with this conclusion. ArKO males (127) are initially fertile, but they develop progressive infertility between 4.5 months and 1 year. In the SPTs of these animals, multiple acrosome vesicles, irregularly scattered 
over the nuclear surface, are observed (127) suggesting that acrosome biogenesis may be an $\mathrm{E}_{2}$-dependent process. Accordingly, P450arom is at high levels in the Golgi complex of developing SPT (120). In ArKO mice, spermatogenesis is primarily arrested at early stages, with a decrease of round and elongated SPT numbers, without any detectable change of circulating FSH levels (127). Dietary phytoestrogens may partially prevent disruption of ArKO mice spermatogenesis, avoiding the decline of germ cell number. Interestingly, when young ArKO mice were exposed to a phytoestrogen free diet, the phenotype was severely disrupted as compared with mice under normal diet. This occurred in absence of a decreased gonadotropic stimulus, suggesting that the effects of dietary phytoestrogens are independent of changes concerning the pituitary-gonadal axis and they are probably related to direct activation of testicular ERs (131). In agreement with this conclusion, $\mathrm{E}_{2}$ administration in irradiated rats suppressed serum LH, FSH, and T (both plasma and intratesticular) levels (132) and produced the recovery of spermatogenesis $(133,134)$ suggesting a gonadotropin-independent $\mathrm{E}_{2}$ activity. However, gynecomastia and cardiovascular problems are secondary effects related to $E_{2}$ treatment and represent the major impediment to clinical application. Recently, it has been suggested that the phytoestrogen genistein may be a true substitute for $\mathrm{E}_{2}$ (135).

Concerning the $C b 1^{-1-}$ mouse, it is a genetically modified animal model showing Cbl-gene deletion (136). This gene codifies CB1, which is broadly expressed in hypothalamus, pituitary, and testis $(137,138)$ of many vertebrates, from fish to mammals [for review see Ref. (52)]. CB1 is involved in GnRH and gonadotropin production $(55-57,139-141)$ at testicular level, it regulates both spermatogenesis $(15,46,58,137,138,142-145)$ and steroidogenesis $(146,147)$. Interestingly, $C b 1^{-1-}$ mice exhibit endocrine features in common with $h p g$ and ArKO models: (1) down regulation of $G n R H$ and $G n R H-R$ mRNA, (2) low LH release and low expression of FSHB mRNA, (3) low T production, and (4) low $\mathrm{E}_{2}$ plasma levels. Morphological and molecular analyses of epididymis and $3 \beta-\mathrm{HSD}$, which are responsive to T, suggest that even low, T levels are enough (55). Unlike $h p g$ and ArKO mice, $C b 1^{-1-}$ mutants are fertile; they show a quantitatively normal production of SPZ although, similarly to some fertile men, a consistent aliquot shows abnormalities $(148,149)$ that are mainly related to the motility and to chromatin quality (histone content, chromatin packaging, DNA integrity, and nuclear size, useful parameters to classify sperm chromatin quality). Therefore, $\mathrm{Cb}^{-1-}$ mice exhibit endocrine and phenotypic features, which are useful to extend the above studies about the role of $\mathrm{E}_{2}$ in SPT differentiation and in the maintenance of sperm quality. Interestingly, when $C b 1^{-1-}$ mice were treated with $\mathrm{E}_{2}$, all the abovementioned chromatin quality indices improved in SPZ $(55,150)$. Therefore, sperm chromatin quality appears to be responsive to $\mathrm{E}_{2}$ treatment (151). Interestingly, $E R \alpha$ and $E R \beta$ polymorphisms have been associated with semen quality (152). Accordingly, P450arom, either mRNA or protein, has been proposed as marker of sperm quality in men. Indeed, Carreau and co-workers reported that, in human ejaculated SPZ, the immotile sperm fraction showed low levels of P450arom, both mRNA and protein activity (30 and 50\%, respectively), as compared with the motile sperm fraction (153-155). In addition, the same authors have recently reported that in SPZ from asthenospermic, teratospermic, and asthenoteratospermic patients, P450arom mRNA levels were progressively lower as compared with SPZ from control patients (156). The hypothesis that $\mathrm{E}_{2}$ treatment improves motility by enhancing oxidative metabolism and the intracellular ATP concentrations in human sperm $(157,158)$ well fit with the observation that $\mathrm{E}_{2}$ can regulate mitochondrial function in MCF7 cells by increasing nuclear respiratory factor-1 expression (159). However, in mouse, $\mathrm{E}_{2}$ and phytoestrogens are able to improve capacitation as well as acrosome reaction and fertilizing capacity of SPZ (160), while natural and synthetic estrogens have stimulatory effect on boar sperm capacitation in vitro (161).

Results from mutant animal models, here reported, in combination with case reports concerning patients with few testicular germ cells or decreased sperm motility and number, have a common root: they are characterized by $\mathrm{E}_{2}$ deficiency due to the mutation or low expression of Cyp19A1 gene ((126, 162-164), suggesting that $\mathrm{E}_{2}$ may have a instrumental role in quality sperm and its action is much more complex than previously predicted or suggested by $\mathrm{ER} \alpha$ knock-out mice, which show impaired fluid re-adsorption within the efferent ducts as cause of sterility (105).

\section{CLOSING REMARKS}

In the last years, data provided by literature evidence that, besides endocrine route, intra-testicular paracrine and autocrine communications are fundamental to sustain spermatogenesis in order to gain high standard quality SPZ. New roles for stereotyped hypothalamic and female hormones $-\mathrm{GnRH}$ and $\mathrm{E}_{2}$, respectively emerged, new potential modulators such as kisspeptins have been identified as well, but conflicting data reveal that several issues need to be further investigated. The modulators here reported - GnRH, kisspeptin, and estrogens - are critical for a successful spermatogenesis as clearly demonstrated by clinical cases of infertility in humans. However, several questions are still open. These different modulators strongly cooperate at hypothalamic level whereas, at testicular level, they control similar events (Leydig cell functions, proliferation/differentiation events, sperm functions); conversely, their possible local crosstalk is far away to be elucidated. Similarly, they may trigger, independently from each other, pathways controlling the same aspects that might represent two sides of the same coin. Both a comparative approach and the use of genetically modified experimental models may represent a successful tool to make giant strides in the building of general models, but to extricate this intriguing story, there is still much to be done.

\section{ACKNOWLEDGMENTS}

Every effort was made to include citation of the most salient findings in the field. We apologize to any author(s) whose work was not adequately cited. Financial support from the "Ministero Italiano dell'Istruzione, dell'Università e della Ricerca" PRIN 2010-2011 to Rosaria Meccariello, and PRIN 2010-2011 to Gilda Cobellis.

\section{AUTHOR CONTRIBUTIONS}

Rosaria Meccariello, conception and design of the work, interpretation of data, manuscript drafting, critical revision, final approval of the submitted version; Rosanna Chianese, acquisition, analysis, 
interpretation of data for the work, manuscript drafting, final approval of the submitted version; Teresa Chioccarelli, acquisition, analysis, interpretation of data for the work, manuscript drafting, final approval of the submitted version; Vincenza Ciaramella, acquisition, analysis, interpretation of data for the work, manuscript drafting, final approval of the submitted version; Silvia Fasano, conception and design of the work, manuscript drafting, critical revision, final approval of the submitted version; Riccardo Pierantoni, conception and design of the work, manuscript drafting, critical revision, final approval of the submitted version; Gilda Cobellis, conception and design of the work, interpretation of data, manuscript drafting, critical revision, final approval of the submitted version.

\section{REFERENCES}

1. Pierantoni R, Cobellis G, Meccariello R, Fasano S. Evolutionary aspects of cellular communication in the vertebrate hypothalamo-hypophysio-gonadal axis. Int Rev Cytol (2002) 218:69-141. doi:10.1016/S0074-7696(02)18012-0

2. Amoss M, Burgus R, Blackwell R, Vale W, Fellows R, Guillemin R. Purification, amino acid composition and N-terminus of the hypothalamic luteinizing hormone releasing factor (LRF) of ovine origin. Biochem Biophys Res Commun (1971) 44:205-10. doi:10.1016/S0006-291X(71)80179-1

3. Kah O, Lethimonier C, Somoza G, Guilgur LG, Vaillant C, Lareyre JJ. GnRH and GnRH receptors in metazoa: a historical, comparative, and evolutive perspective. Gen Comp Endocrinol (2007) 153:346-64. doi:10.1016/j.ygcen.2007. 01.030

4. Kavanaugh SI, Nozaki M, Sower SA. Origins of gonadotropin-releasing hormone $(\mathrm{GnRH})$ in vertebrates: identification of a novel $\mathrm{GnRH}$ in a basal vertebrate, the sea lamprey. Endocrinology (2008) 149:3860-9. doi:10.1210/en. 2008-0184

5. Millar RP, Lu ZL, Pawson AJ, Flanagan CA, Morgan K, Maudsley SR. Gonadotropin-releasing hormone receptors. Endocr Rev (2004) 25:235-75. doi:10.1210/er.2003-0002

6. Morgan K, Millar RP. Evolution of GnRH ligand precursors and GnRH receptors in protochordate and vertebrate species. Gen Comp Endocrinol (2004) 139:191-7. doi:10.1016/j.ygcen.2004.09.015

7. Oh DY, Song JA, Moon JS, Moon MJ, Kim JI, Kim K, et al. Membraneproximal region of the carboxyl terminus of the gonadotropin-releasing hormone receptor (GnRHR) confers differential signal transduction between mammalian and nonmammalian GnRHRs. Mol Endocrinol (2005) 19:722-31. doi:10.1210/me.2004-0220

8. King JA, Millar RP. Evolutionary aspects of gonadotropin-releasing hormone and its receptor. Cell Mol Neurobiol (1995) 15:5-23. doi:10.1007/BF02069556

9. Wu HM, Cheng JC, Wang HS, Huangm HY, MacCalman CD, Leung PC. Gonadotropin-releasing hormone type II induces apoptosis of human endometrial cancer cells by activating GADD45alpha. Cancer Res (2009) 69:4202-8. doi:10.1158/0008-5472.CAN-08-4591

10. Aguilar-Rojas A, Huerta-Reyes M. Human gonadotropin-releasing hormone receptor-activated cellular functions and signaling pathways in extra-pituitary tissues and cancer cells. Oncol Rep (2009) 22:981-90. doi:10.3892/or_00000525

11. Pawson AJ, Morgan K, Maudsley SR, Millar RP. Type II gonadotrophinreleasing hormone (GnRH-II) in reproductive biology. Reproduction (2003) 126:271-8. doi:10.1530/rep.0.1260271

12. Sharpe RM. Paracrine control of the testis. Clin Endocrinol Metab (1986) 15:185-207. doi:10.1016/S0300-595X(86)80049-4

13. Morales P, Pizzarro E, Kong M, Kerr B, Ceric F, Vigil P. Gonadotropin releasing hormone stimulated sperm binding to the human zona is mediated by a calcium influx. Biol Reprod (2000) 63:635-42. doi:10.1095/biolreprod63.2.635

14. Morales P, Pasten C, Pizzarro E. Inhibition of in vivo and in vivo fertilization in rodents by gonadotropin-releasing hormone antagonist. Biol Reprod (2002) 67:1360-5. doi:10.1095/biolreprod67.4.1360

15. Pierantoni R, Cobellis G, Meccariello R, Cacciola G, Chianese R, Chioccarelli T, et al. Testicular gonadotropin-releasing hormone activity, progression of spermatogenesis, and sperm transport in vertebrates. Ann N Y Acad Sci (2009) 1163:279-91. doi:10.1111/j.1749-6632.2008.03617.x
16. Chianese R, Chioccarelli T, Cacciola G, Ciaramella V, Fasano S, Pierantoni $\mathrm{R}$, et al. The contribution of lower vertebrate animal models in human reproduction research. Gen Comp Endocrinol (2011) 171:17-27. doi:10.1016/ j.ygcen.2010.12.011

17. Bahk JY, Hyun JS, Chung SH, Lee H, Kim MO, Lee BH, et al. Stage specific identification of the expression of GnRH mRNA and localization of the GnRH receptor in mature rat and adult human testis. J Urol (1995) 154:1958-61. doi:10.1097/00005392-199511000-00105

18. White RB, Fernald RD. Genomic structure and expression sites of three gonadotropin-releasing hormone genes in one species. Gen Comp Endocrinol (1998) 112:217-25. doi:10.1006/gcen.1998.7125

19. van Biljon W, Wykes S, Scherer S, Krawetz SA, Hapgood J. Type II gonadotropinreleasing hormone receptor transcripts in human sperm. Biol Reprod (2002) 67:1741-9. doi:10.1095/biolreprod.101.002808

20. Millar R, Conklin D, Lofton-Day C, Hutchinson E, Troskie B, Illing N, et al. A novel human GnRH receptor homolog gene: abundant and wide tissue distribution of the antisense transcript. J Endocrinol (1999) 162:117-26. doi:10.1677/joe.0.1620117

21. Pierantoni R, Fasano S, Di Matteo L, Minucci S, Varriale B, Chieffi G. Stimulatory effect of a GnRH agonist (buserelin) in in vitro and in vivo testosterone production by the frog (Rana esculenta) testis. Mol Cell Endocrinol (1984) 38:215-9. doi:10.1016/0303-7207(84)90120-5

22. Ramakrishnappa N, Rajamahendran R, Lin YM, Leung PC. GnRH in nonhypothalamic reproductive tissues. Anim Reprod Sci (2005) 88:95-113. doi:10. 1016/j.anireprosci.2005.05.009

23. Lin YM, Liu MY, Poon SL, Leu SF, Huang BM. Gonadotropin-releasing hormone-I and -II stimulate steroidogenesis in prepubertal murine Leydig cells in vitro. Asian J Androl (2008) 10:929-36. doi:10.1111/j.1745-7262.2008. 00434.x

24. Fasano S, Pierantoni R, Minucci S, Di Matteo L, D’Antonio M, Chieffi G. Effects of intratesticular injections of estradiol and gonadotropin-releasing hormone (GnRHA, HOE 766) on plasma androgen levels in intact and hypophysectomized Torpedo marmorata and Torpedo ocellata. Gen Comp Endocrinol (1989) 75:349-54. doi:10.1016/0016-6480(89)90169-X

25. King JA, Millar RP, Vallarino M, Pierantoni R. Localization and characterization of gonadotropin-releasing hormones in the brain, gonads, and plasma of a dipnoi (lungfish, Protopterus annectens). Regul Pept (1995) 57:163-74. doi:10.1016/0167-0115(95)00025-7

26. Lin YM, Poon SL, Choi JH, Lin JS, Leung PC, Huang BM. Transcripts of testicular gonadotropin-releasing hormone, steroidogenic enzymes, and intratesticular testosterone levels in infertile men. Fertil Steril (2008) 90:1761-8. doi:10.1016/j.fertnstert.2007.08.078

27. Yao B, Liu HY, Gu YC, Shi SS, Tao XQ, Li XJ, et al. Gonadotropin-releasing hormone positively regulates steroidogenesis via extracellular signal-regulated kinase in rat Leydig cells. Asian J Androl (2011) 13:438-45. doi:10.1038/aja. 2010.158

28. Anjum S, Krishna A, Sridaran R, Tsutsui K. Localization of gonadotropinreleasing hormone $(\mathrm{GnRH})$, gonadotropin-inhibitory hormone $(\mathrm{GnIH})$, kisspeptin and GnRH receptor and their possible roles in testicular activities from birth to senescence in mice. J Exp Zool A Ecol Genet Physiol (2012) 317:630-44. doi:10.1002/jez.1765

29. Ubuka T, Son YL, Tobari J, Narihiro M, Bentley GE, Kriegsfelf LJ, et al. Central and direct regulation of testicular activity by gonadotropin-inhibitory hormone and its receptor. Front Endocrinol (2014) 5:8. doi:10.3389/fendo.2014. 00008

30. Guo JJ, Ma X, Wang CQ, Ge YF, Lian QQ, Hardy DO, et al. Effect of luteinizing hormone and androgen on the development of rat progenitor Leydig cells in vitro and in vivo. Asian J Androl (2013) 15:685-91. doi:10.1038/aja.2013.55

31. So WK, Cheng JC, Poon SL, Leung PC. Gonadotropin-releasing hormone and ovarian cancer: a functional and mechanistic overview. FEBS J (2008) 275:5496-511. doi:10.1111/j.1742-4658.2008.06679.x

32. White CD, Stewart AJ, Lu ZL, Millar RP, Morgan K. Antiproliferative effects of GnRH agonists: prospects and problems for cancer therapy. Neuroendocrinology (2008) 88:67-79. doi:10.1159/000119093

33. Andreu-Vieyra CV, Buret AG, Habibi HR. Gonadotropin-releasing hormone induction of apoptosis in the testes of goldfish (Carassius auratus). Endocrinology (2005) 146:1588-96. doi:10.1210/en.2004-0818 
34. Soverchia L, Carotti M, Andreu-Vieyra C, Mosconi G, Cannella N, Habibi H, et al. Role of gonadotropin-releasing hormone $(\mathrm{GnRH})$ in the regulation of gonadal differentiation in the gilthead seabream (Sparus aurata). Mol Reprod Dev (2007) 74:57-67. doi:10.1002/mrd.20484

35. Ogawa T, Dobrinski I, Avarbock MR, Brinster RL. Leuprolide, a gonadotropinreleasing hormone agonist, enhances colonization after spermatogonial transplantation into mouse testes. Tissue Cell (1998) 30:583-8. doi:10.1016/S00408166(98)80039-6

36. Ogawa T, Dobrinski I, Brinster RL. Recipient preparation is critical for spermatogonial transplantation in the rat. Tissue Cell (1999) 31:461-72. doi:10.1054/tice.1999.0060

37. Shuttlesworth GA, de Rooij DG, Huhtaniemi I, Reissmann T, Russel LD, Shetty $\mathrm{G}$, et al. Enhancement of a spermatogonial proliferation and differentiation in irradiated rats by gonadotropin-releasing hormone antagonist administration. Endocrinology (2000) 141:37-49. doi:10.1210/en.141.1.37

38. Treen N, Itoh N, Miura H, Kikuchi I, Ueda T, Takahashi KG, et al. Mollusc gonadotropin-releasing hormone directly regulates gonadal functions: a primitive endocrine system controlling reproduction. Gen Comp Endocrinol (2012) 176:167-72. doi:10.1016/j.ygcen.2012.01.008

39. Minucci S, Di Matteo L, Pierantoni R, Varriale B, Rastogi RK, Chieffi G. In vivo and in vitro stimulatory effect of a gonadotropin-releasing hormone ana$\log$ (HOE 766) on spermatogonial multiplication in the frog, Rana esculenta. Endocrinology (1986) 119:731-6. doi:10.1210/endo-119-2-731

40. Minucci S, Fasano S, Pierantoni R. Induction of S-phase entry by a gonadotropin releasing hormone agonist (buserelin) in the frog, Rana esculenta, primary spermatogonia. Comp Biochem Physiol C Pharmacol Toxicol Endocrinol (1996) 113:99-102. doi:10.1016/0742-8413(95)02046-2

41. Di Matteo L, Minucci S, Fasano S, Pierantoni R, Varriale B, Chieffi G. A gonadotropin-releasing hormone $(\mathrm{GnRH})$ antagonist decreases androgen production and spermatogonial multiplication in frog (Rana esculenta): indirect evidence for the existence of GnRH or GnRH-like material receptors in the hypophysis and testis. Endocrinology (1988) 122:62-7. doi:10.1210/endo-1221-62

42. Cobellis G, Meccariello R, Fienga G, Pierantoni R, Fasano S. Cytoplasmic and nuclear Fos protein forms regulate resumption of spermatogenesis in the frog, Rana esculenta. Endocrinology (2002) 143:163-70. doi:10.1210/en.143.1.163

43. Cobellis G, Meccariello R, Minucci S, Palmiero C, Pierantoni R, Fasano S. Cytoplasmic versus nuclear localization of Fos-related proteins in the frog, Rana esculenta, testis: in vivo and direct in vitro effect of a gonadotropin-releasing hormone agonist. Biol Reprod (2003) 68:954-60. doi:10.1095/biolreprod.102. 008938

44. Savulescu D, Feng J, Ping YS, Mai O, Boehm U, He B, et al. Gonadotropinreleasing hormone-regulated prohibitin mediates apoptosis of the gonadotrope cells. Mol Endocrinol (2013) 27:1856-70. doi:10.1210/me.2013-1210

45. Minucci S, Di Matteo L, Chieffi Baccari G, Pierantoni R. A gonadotropin releasing hormone analog induces spermiation in intact and hypophysectomized frogs, Rana esculenta. Experientia (1989) 45:1118-21. doi:10.1007/BF01950175

46. Chianese R, Ciaramella V, Scarpa D, Fasano S, Pierantoni R, Meccariello R. Anandamide regulates the expression of GnRH1, GnRH2 and GnRHRs in frog testis. Am J Physiol Endocrinol Metab (2012) 303:E475-87. doi:10.1152/ ajpendo.00086.2012

47. Zerani M, Catone G, Quassinti L, Maccari E, Bramucci M, Gobbetti A, et al. In vitro effects of gonadotropin-releasing hormone $(\mathrm{GnRH})$ on Leydig cells of adult alpaca (Lama pacos) testis: GnRH receptor immunolocalization, testosterone and prostaglandin synthesis, and cyclooxygenase activities. Domest Anim Endocrinol (2011) 40:51-9. doi:10.1016/j.domaniend.2010.08.006

48. Chianese R, Ciaramella V, Fasano S, Pierantoni R, Meccariello R. Anandamide modulates the expression of GnRH-II and GnRHRs in frog, Rana esculenta, diencephalon. Gen Comp Endocrinol (2011) 173:389-95. doi:10.1016/j.ygcen. 2011.07.001

49. Cacciola G, Chianese R, Chioccarelli T, Ciaramella V, Fasano S, Pierantoni R, et al. Cannabinoid and reproduction: a lasting and intriguing history. Pharmaceuticals (2010) 3:3275-323. doi:10.3390/ph3103275

50. Pierantoni R, Cobellis G, Meccariello R, Cacciola G, Chianese R, Chioccarelli $\mathrm{T}$, et al. CB1 activity in male reproduction: mammalian and nonmammalian anima models. Vitam Horm (2009) 81:367-87. doi:10.1016/S0083-6729(09) 81014-5

51. Battista N, Meccariello R, Cobellis G, Fasano S, Di Tommaso M, Pirazzi V, et al. The role of endocannabinoids in gonadal function and fertility along the evolutionary axis. Mol Cell Endocrinol (2012) 355:1-14. doi:10.1016/j.mce. 2012.01.014

52. Meccariello R, Battista N, Bradshaw HB, Wang H. Updates in reproduction coming from the endocannabinoid system. Int J Endocrinol (2014) 2014(412354):16. doi:10.1155/2014/412354

53. Scorticati C, Fernandez-Solari J, De Laurentiis A, Mohn C, Prestifilippo JP, Lasaga $\mathrm{M}$, et al. The inhibitory effect of anandamide on luteinizing hormonereleasing hormone secretion is reversed by oestrogen. Proc Natl Acad Sci U S A (2004) 32:11891-6. doi:10.1073/pnas.0404366101

54. Farkas I, Kallo I, Deli L, Vida B, Hrabovszky E, Fekete C, et al. Retrograde endocannabinoids signaling reduces GABAergic synaptic transmission to gonadotropin-releasing hormone neurons. Endocrinology (2010) 151:5818-29. doi:10.1210/en.2010-0638

55. Cacciola G, Chioccarelli T, Altucci L, Ledent C, Mason JI, Fasano S, et al. Low 17beta-estradiol levels in CNR1 knock-out mice affect spermatid chromatin remodeling by interfering with chromatin reorganization. Biol Reprod (2013) 152:1-12. doi:10.1095/biolreprod.112.105726

56. Meccariello R, Franzoni MF, Chianese R, Cottone E, Scarpa D, Donna D, et al. Interplay between the endocannabinoid system and $G n R H-I$ in the forebrain oh the anuran amphibian Rana esculenta. Endocrinology (2008) 149:2149-58. doi:10.1210/en.2007-1357

57. Chianese R, Cobellis G, Pierantoni R, Fasano S, Meccariello R. Nonmammalian vertebrate models and the endocannabinoid system: relationships with gonadotropin-releasing hormone. Mol Cell Endocrinol (2008) 286:S46-51. doi:10.1016/j.mce.2008.01.009

58. Chianese R, Ciaramella V, Scarpa D, Fasano S, Pierantoni R, Meccariello R. Endocannabinoids and endovanilloids: a possible balance in the regulation of testicular GnRH signaling. Int J Endocrinol (2013) 2013:904748. doi:10.1155/2013/904748

59. Lee JH, Miele ME, Hicks DJ, Phillips KK, Trent JM, Weissman BE, et al. Kiss-1, a novel human malignant melanoma metastasis-suppressor gene. J Natl Cancer Inst (1996) 88:1731-7. doi:10.1093/jnci/88.23.1731

60. Kotani M, Detheux M, Vandenbogaerde A, Communi D, Vanderwinden JM, Le Poul E, et al. The metastasis suppressor gene Kiss-1 encodes kisspeptins, the natural ligands of the orphan $\mathrm{G}$ protein-coupled receptor GPR54. J Biol Chem (2001) 276:34631-6. doi:10.1074/jbc.M104847200

61. Messager S, Chatzidaki EE, Ma D, Hendrick AG, Zahn D, Dixon J, et al. Kisspeptin directly stimulates gonadotropin releasing hormone release via $\mathrm{G}$ protein coupled receptor 54. Proc Natl Acad Sci U S A (2005) 102:1761-6. doi:10.1073/pnas.0409330102

62. Seminara SB, Messager S, Chatzidaki EE, Thresher RR, Acierno JS, Shagoury JK, et al. The GPR54 gene as a regulator of puberty. N Engl J Med (2003) 349:1614-27. doi:10.1056/NEJMoa035322

63. de Roux N, Genin E, Carel JC, Matsuda F, Chaussain JL, Milgrom E. Hypogonadotropic hypogonadism due to loss of function of the KiSS1-derived peptide receptor GPR54. Proc Natl Acad Sci U S A (2003) 100:10972-6. doi:10.1073/pnas.1834399100

64. Beck BH, Fuller SA, Peatman E, McEntire ME, Darwish A, Freeman DW. Chronic exogenous kisspeptin administration accelerates gonadal development in basses of the genus Morone. Comp Biochem Physiol A Mol Integr Physiol (2012) 162:265-73. doi:10.1016/j.cbpa.2012.03.019

65. Nocillado JN, Zohar Y, Biran J, Levavi-Sivan B, Elizur A. Chronic kisspeptin administration stimulated gonadal development in pre-pubertal male yellowtail kingfish (Seriola lalandi; perciformes) during the breeding and nonbreeding season. Gen Comp Endocrinol (2013) 191:168-76. doi:10.1016/j. ygcen.2013.06.005

66. Selvaraj S, Ohga H, Nyuji M, Kitano H, Nagano N, Yamaguchi A, et al. Subcutaneous administration of Kiss1 pentadecapeptide accelerates spermatogenesis in prepubertal male chub mackerel (Scomber japonicus). Comp Biochem Physiol A Mol Integr Physiol (2013) 166:228-36. doi:10.1016/j.cbpa.2013.06.007

67. Selvaraj S, Ohga H, Kitano H, Nyuji M, Yamaguchi A, Matsuyama M. Peripheral administration of Kiss1 pentadecapeptide induces gonadal development in sexually immature adult scombroid fish. Zoolog Sci (2013) 30:446-54. doi:10.2108/zsj.30.446

68. Saito H, Sawada T, Yaegashi T, Goto Y, Jin J, Sawai K, et al. Kisspeptin-10 stimulates the release of luteinizing hormone and testosterone in pre- and post-pubertal male goats. Anim Sci J (2012) 83:487-92. doi:10.1111/j.17400929.2011.00978.x 
69. Kauffman AS. Coming of age in the kisspeptin era: sex differences, development, and puberty. Mol Cell Endocrinol (2010) 324:51-63. doi:10.1016/j.mce. 2010.01.017

70. Demirbilek H, Gonc EN, Ozon A, Alikasifoglu A, Kandemir N. Evaluation of serum kisspeptin levels in girls in the diagnosis of central precocious puberty and in the assessment of pubertal suppression. J Pediatr Endocrinol Metab (2012) 25:313-6. doi:10.1515/jpem-2011-0445

71. Ratnasabapathy R, Dhillo WS. The effects of kisspeptin in human reproductive function therapeutic implications. Curr Drug Targets (2013) 14:365-71. doi:10.2174/138945013804998981

72. Oakley AE, Clifton DK, Steiner RA. Kisspeptin signaling in the brain. Endocr Rev (2009) 30:713-43. doi:10.1210/er.2009-0005

73. Mayer C, Boehm U. Female reproductive maturation in the absence of kisspeptin/GPR54 signaling. Nat Neurosci (2011) 14:704-10. doi:10.1038/nn. 2818

74. Popa SM, Moriyama RM, Caligioni CS, Yang JJ, Cho CM, Concepcion TL, et al. Redundancy in Kiss 1 expression safeguards reproduction in the mouse. Endocrinology (2013) 154:2784-94. doi:10.1210/en.2013-1222

75. Ohtaki T, Shintani Y, Honda S, Matsumoto H, Hori A, Kanehashi K, et al. Metastasis suppressor gene KiSS-1 encodes peptide ligand of a G-protein-coupled receptor. Nature (2001) 411:613-7. doi:10.1038/35079135

76. Funes S, Hedrick JA, Vassileva G, Markowitz L, Abbondanzo S, Golovko A, et al. The KiSS-1 receptor GPR54 is essential for the development of the murine reproductive system. Biochem Biophys Res Commun (2003) 312:1357-63. doi:10.1016/j.bbrc.2003.11.066

77. Terao Y, Kumano S, Takatsu Y, Hattori M, Nishimura A, Ohtaki T, et al. Expression of KiSS-1, a metastasis suppressor gene, in trophoblast giant cells of the rat placenta. Biochim Biophys Acta (2004) 1678:102-10. doi:10.1016/j.bbaexp. 2004.02.005

78. Tariq AR, Shahab M, Clarke IJ, Pereira A, Smith JT, Khan SH, et al. Kiss1 and kiss1 receptor expression in the rhesus monkey testis: a possible local regulator of testicular function. Cent Eur J Biol (2013) 8:968-74. doi:10.2478/s11535013-0219-4

79. Irfan S, Ehmcke J, Wahab F, Shahab M, Schlatt S. Intratesticular action of kisspeptin in rhesus monkey (Macaca mulatta). Andrologia (2013). doi:10. 1111 /and.12121

80. Chianese R, Ciaramella V, Fasano S, Pierantoni R, Meccariello R. Kisspeptin receptor, GPR54, as a candidate for the regulation of testicular activity in the frog Rana esculenta. Biol Reprod (2013) 88:73. doi:10.1095/biolreprod.112. 103515

81. Ramzan F, Qureshi IZ. Intraperitoneal kisspeptin-10 administration induces dose-dependent degenerative changes in maturing rat testes. Life Sci (2011) 88:246-56. doi:10.1016/j.lfs.2010.11.019

82. Thompson EL, Murphy KG, Patterson M, Bewick GA, Stamp GW, Curtis AE, et al. Chronic subcutaneous administration of kisspeptin-54 causes testicular degeneration in adult male rats. Am J Physiol Endocrinol Metab (2006) 291:E1074-82. doi:10.1152/ajpendo.00040.2006

83. Ramzan F, Qureshi IZ, Ramzan M, Ramzan MH, Ramzan F. Immature rat seminal vesicles show histomorphological and ultrastructural alterations following treatment with kisspeptin-10. Reprod Biol Endocrinol (2012) 10:18 doi:10.1186/1477-7827-10-18

84. Ramzan F, Qureshi IZ, Ramzan M, Ramzan MH, Ramzan F. Kisspeptin10 induces dose dependent degeneration in prepubertal rat prostate gland. Prostate (2013) 73:690-9. doi:10.1002/pros.22609

85. Mei H, Doran J, Kyle V, Yeo SH, Colledge WH. Does kisspeptin signalling have a role in the testes? Front Endocrinol (2013) 4:198. doi:10.3389/fendo.2013.00198

86. Shahab M, Mastronardi C, Seminara SB, Crowley WF, Ojeda SR, Plant TM. Increased hypothalamic GPR54 signaling: a potential mechanism for initiation of puberty in primates. Proc Natl Acad Sci U S A (2005) 102:2129-34. doi:10.1073/pnas.0409822102

87. Roseweir AK, Kauffman AS, Smith JT, Guerriero KA, Morgan K, PieleckaFortuna J, et al. Discovery of potent kisspeptin antagonists delineate physiological mechanisms of gonadotropin regulation. J Neurosci (2009) 29:3920-9. doi:10.1523/JNEUROSCI.5740-08.2009

88. Pinto FM, Cejudo-Román A, Ravina CG, Fernández-Sánchez M, MartínLozano D, Illanes M, et al. Characterization of the kisspeptin system in human spermatozoa. Int J Androl (2012) 35:63-73. doi:10.1111/j.1365-2605.2011. 01177.x
89. Hsu MC, Wang JY, Lee YJ, Jong DS, Tsui KH, Chiu CH. Kisspeptin modulates fertilization capability of mouse spermatozoa. Reproduction (2014). doi:10.1530/REP-13-0368

90. Pierantoni R, Cobellis G, Meccariello R, Palmiero C, Fienga G, Minucci S, et al. The amphibian testis as model to study germ cell progression during spermatogenesis. Biochem Physiol B Biochem Mol Biol (2002) 132:131-9. doi:10.1016/S1096-4959(01)00543-7

91. Rastogi RK, Iela L, Saxena PK, Chieffi G. The control of spermatogenesis in the green frog, Rana esculenta. J Exp Zool (1976) 169:151-66. doi:10.1002/jez. 1401960203

92. Fasano S, Minucci S, Di Matteo L, D’Antonio M, Pierantoni R. Intratesticular feedback mechanisms in the regulation of steroid profiles in the frog, Rana esculenta. Gen Comp Endocrinol (1989) 75:335-42. doi:10.1016/0016-6480(89) 90167-6

93. Sirianni R, Chimento A, Ruggiero C, De Luca A, Lappano R, Andò S, et al. The novel estrogen receptor, $G$ protein-coupled receptor 30 , mediates the proliferative effects induced by 17beta-estradiol on mouse spermatogonial GC-1 cell line. Endocrinology (2008) 149:5043-51. doi:10.1210/en.2007-1593

94. Chimento A, Sirianni R, Casaburi I, Pezzi V. Role of estrogen receptors (ERs) and $G$ protein-coupled estrogen receptor (GPER) in regulation of hypothalamic-pituitary-testis axis and spermatogenesis. Front Endocrinol (2014) 5:1. doi:10.3389/fendo.2014.00001

95. Lidke AK, Bannister S, Löwer AM, Apel DM, Podleschny M, Kollmann M, et al. $17 \beta$-Estradiol induces supernumerary primordial germ cells in embryos of the polychaete Platynereis dumerilii. Gen Comp Endocrinol (2014) 196:52-61. doi:10.1016/j.ygcen.2013.11.017

96. Huma T, Ullah F, Hanif F, Rizak JD, Shahab M. Peripheral administration of kisspeptin antagonist does not alter basal plasma testosterone but decreases plasma adiponectin levels in adult male rhesus macaques. Eur J Sci Res (2013) 109:668-77. doi:10.3906/biy-1401-53

97. Carreau S, Bouraima-Lelong H, Delalande C. Estrogens in male germ cells. Spermatogenesis (2011) 1:90-4. doi:10.4161/spmg.1.2.16766

98. Maggiolini M, Picard D. The unfolding stories of GPR30, a new membranebound estrogen receptor. J Endocrinol (2010) 204:105-14. doi:10.1677/JOE09-0242

99. Liu X, Zhu P, Sham KW, Yuen JM, Xie C, Zhang Y, et al. Identification of a membrane estrogen receptor in zebrafish with homology to mammalian GPR30 and its high expression in early germ cells of the testis. Biol Reprod (2009) 80:1253-61. doi:10.1095/biolreprod.108.070250

100. Chimento A, Sirianni R, Delalande C, Silandre D, Bois C, Andò S, et al. 17 Betaestradiol activates rapid signaling pathways involved in rat pachytene spermatocytes apoptosis through GPR30 and ER alpha. Mol Cell Endocrinol (2010) 320:136-44. doi:10.1016/j.mce.2010.01.035

101. Alves MG, Socorro S, Silva J, Barros A, Sousa M, Cavaco JE, et al. In vitro cultured human Sertoli cells secrete high amounts of acetate that is stimulated by $17 \beta$-estradiol and suppressed by insulin deprivation. Biochim Biophys Acta (2012) 1823:1389-94. doi:10.1016/j.bbamcr.2012.06.002

102. Rago V, Romeo F, Giordano F, Maggiolini M, Carpino A. Identification of the estrogen receptor GPER in neoplastic and non-neoplastic human testes. Reprod Biol Endocrinol (2011) 9:135. doi:10.1186/1477-7827-9-135

103. O’Donnell L, Robertson KM, Jones ME, Simpson ER. Estrogen and spermatogenesis. Endocr Rev (2001) 22:289-318. doi:10.1210/er.22.3.289

104. Shanbacker BD. Regulation of luteinizing hormone secretion in male sheep by endogenous estrogen. Endocrinology (1974) 115:944-50. doi:10.1210/endo115-3-944

105. Eddy EM, Washburn TF, Bunch DO, Goulding EH, Gladen BC, Lubahn $\mathrm{DB}$, et al. Targeted disruption of the estrogen receptor gene in male mice causes alteration of spermatogenesis and infertility. Endocrinology (1996) 137:4796-805. doi:10.1210/en.137.11.4796

106. Hess RA, Bunick D, Lee KH, Bahr J, Taylor JA, Korach KS, et al. A role for oestrogens in the male reproductive system. Nature (1997) 390:509-12. doi: $10.1038 / 37352$

107. Miura T, Miura C, Ohta T, Nader MR, Todo T, Yamauchi K. Estradiol-17ß stimulates the renewal of spermatogonial stem cells in males. Biochem Biophys Res Commun (1999) 264:230-4. doi:10.1006/bbrc.1999.1494

108. Cobellis G, Pierantoni R, Minucci S, Pernas-Alonso R, Meccariello R, Fasano S. c-Fos activity in Rana esculenta testis: seasonal and estradiol-induced changes. Endocrinology (1999) 140:3238-44. doi:10.1210/en.140.7.3238 
109. Cobellis G, Lombardi M, Scarpa D, Izzo G, Fienga G, Meccariello R, et al. Fra-1 activity in the frog, Rana esculenta, testis. Ann N Y Acad Sci (2005) 1040:264-8. doi:10.1196/annals.1327.039

110. Cobellis G, Lombardi M, Scarpa D, Izzo G, Fienga G, Meccariello R, et al. Fral activity in the frog, Rana esculenta, testis: a new potential role in sperm transport. Biol Reprod (2005) 72:1101-8. doi:10.1095/biolreprod.104. 036541

111. Cobellis G, Cacciola G, Chioccarelli T, Izzo G, Meccariello R, Pierantoni R, et al. Estrogen regulation of the male reproductive tract in the frog, Rana esculenta: a role in Fra-1 activation in peritubular myoid cells and in sperm release. Gen Comp Endocrinol (2008) 155:838-46. doi:10.1016/j.ygcen.2007.10.004

112. Lucas TF, Pimenta MT, Pisolato R, Lazari MF, Porto CS. 17Beta-estradiol signaling and regulation of Sertoli cell function. Spermatogenesis (2011) 1:318-24. doi:10.4161/spmg.1.4.18903

113. Ruwanpura SM, McLachlan RI, Meachem SJ. Hormonal regulation of male germ cell development. J Endocrinol (2010) 205:117-31. doi:10.1677/JOE-100025

114. Shetty G, Krishnamurthy H, Krishnamurthy HN, Bhatnagar S, Moudgal RN. Effect of estrogen deprivation on the reproductive physiology of male and female primates. J Steroid Biochem Mol Biol (1997) 61:157-66. doi:10.1016/ S0960-0760(97)80008-8

115. Shetty G, Krishnamurthy H, Krishnamurthy HN, Bhatnagar AS, Moudgal NR. Effect of long-term treatment with aromatase inhibitor on testicular function of adult male bonnet monkeys (M. radiata). Steroids (1998) 63:414-20. doi:10.1016/S0039-128X(98)00042-7

116. Staub C, Rauch M, Ferrière F, Trépos M, Dorval-Coiffec I, Saunders PT, et al. Expression of estrogen receptor ESR1 and its 46-kDa variant in the gubernaculum testis. Biol Reprod (2005) 73:703-12. doi:10.1095/biolreprod.105.042796

117. Schulz RW, de França LR, Lareyre JJ, Le Gac F, Chiarini-Garcia H, Nobrega RH, et al. Spermatogenesis in fish. Gen Comp Endocrinol (2010) 165:390-411. doi:10.1016/j.ygcen.2009.02.013

118. Rolland AD, Lareyre JJ, Goupil AS, Montfort J, Ricordel MJ, Esquerré D, et al. Expression profiling of rainbow trout testis development identifies evolutionary conserved genes involved in spermatogenesis. BMC Genomics (2009) 10:546. doi:10.1186/1471-2164-10-546

119. Pinto PI, Teodósio HR, Galay-Burgos M, Power DM, Sweeney GE, Canário AV. Identification of estrogen-responsive genes in the testis of sea bream (Sparus auratus) using suppression subtractive hybridization. Mol Reprod Dev (2006) 73:318-29. doi:10.1002/mrd.20402

120. Nitta H, Bunick D, Hess RA, Janulis L, Newton SC, Milette CF, et al. Germ cells of the mouse testis express P450 aromatase. Endocrinology (1993) 132:1396-401. doi:10.1210/en.132.3.1396

121. Carreau S, Bouraima-Lelong H, Delalande C. Role of estrogens in spermatogenesis. Front Biosci (Elite Ed) (2012) 4:1-11. doi:10.2741/356

122. Tsutsumi I, Toppari J, Campeau JD, Di Zerega GS. Reduction of fertility in the male rat by systemic treatment with follicle regulatory protein. Fertil Steril (1987) 47:689-95.

123. Tsutsumi I, Fugimori K, Nakamura RM. Disruption of seminiferous epithelial function in the rat by ovarian protein. Biol Reprod (1987) 36:451-61. doi:10.1095/biolreprod36.2.451

124. D’Souza R, Gill-Sharma MK, Pathak S, Kedia N, Kumar R, Balasinor N. Effect of high intratesticular estrogen on the seminiferous epithelium in adult male rats. Mol Cell Endocrinol (2005) 241:41-8. doi:10.1016/j.mce.2005.04.011

125. Pentikäinen V, Erkkilä K, Suomalainen L, Parvinen M, Dunkel L. Estradiol acts as a germ cell survival factor in the human testis in vitro. J Clin Endocrinol Metab (2000) 85:2057-67. doi:10.1210/jcem.85.5.6600

126. Lanfranco F, Zirilli L, Baldi M, Pignatti E, Corneli G, Ghigo E, et al. A novel mutation in the human aromatase gene: insights on the relationship among serum estradiol, longitudinal growth and bone mineral density in an adult man under estrogen replacement treatment. Bone (2008) 43:628-35. doi:10.1016/j.bone.2008.05.011

127. Robertson KM, O’Donnell L, Jones ME, Meachem SJ, Boon WC, Fisher CR, et al. Impairment of spermatogenesis in mice lacking a functional aromatase (cyp 19) gene. Proc Natl Acad Sci U S A (1999) 96:7986-91. doi:10.1073/pnas. 96.14.7986

128. Ebling FJ, Brooks AN, Cronin AS, Ford H, Kerr JB. Estrogenic induction of spermatogenesis in the hypogonadal mouse. Endocrinology (2000) 141:2861-9. doi:10.1210/en.141.8.2861
129. Allan CM, Couse JF, Simanainen U, Spaliviero J, Jimenez M, Rodriguez K, et al. Estradiol induction of spermatogenesis is mediated via an estrogen receptorfalphag mechanism involving neuroendocrine activation of follicle-stimulating hormone secretion. Endocrinology (2010) 151:2800-10. doi:10.1210/en.20091477

130. Baines H, Nwagwu MO, Hastie GR, Wiles RA, Mayhew TM, Ebling FJ. Effects of estradiol and FSH on maturation of the testis in the hypogonadal (hpg) mouse. Reprod Biol Endocrinol (2008) 6:4. doi:10.1186/1477-7827-6-4

131. Robertson KM, O'Donnell L, Simpson ER, Jones ME. The phenotype of the aromatase knockout mouse reveals dietary phytoestrogens impact significantly on testis function. Endocrinology (2002) 143:2913-21. doi:10.1210/en.143.8.2913

132. Shetty G, Weng CC, Bolden-Tiller OU, Huhtaniemi I, Handelsman DJ, Meistrich ML. Effects of medroxyprogesterone and estradiol on the recovery of spermatogenesis in irradiated rats. Endocrinology (2004) 145:4461-9. doi:10.1210/en.2004-0440

133. Zhou W, Bolden-Tiller OU, Shao SH, Weng CC, Shetty G, AbuElhija M, et al. Estrogen-regulated genes in rat testes and their relationship to recovery of spermatogenesis after irradiation. Biol Reprod (2011) 85:823-33. doi:10.1095/ biolreprod.111.091611

134. Porter KL, Shetty G, Shuttlesworth GA, Weng CC, Huhtaniemi I, Pakarinen $\mathrm{P}$, et al. Estrogen enhances recovery from radiation-induced spermatogonial arrest in rat testes. J Androl (2009) 30:440-51. doi:10.2164/jandrol.108.006635

135. Chi H, Chun K, Son H, Kim J, Kim G, Roh S. Effect of genistein administration on the recovery of spermatogenesis in the busulfan-treated rat testis. Clin Exp Reprod Med (2013) 40:60-6. doi:10.5653/cerm.2013.40.2.60

136. Ledent C, Valverde O, Cossu G, Petitet F, Aubert JF, Beslot F, et al. Unresponsiveness to cannabinoids and reduced addictive effects of opiates in CB1 receptor knockout mice. Science (1999) 283:401-4. doi:10.1126/science.283.5400.401

137. Cobellis G, Cacciola G, Scarpa D, Meccariello R, Chianese R, Franzoni MF, et al. Endocannabinoid system in frog and rodent testis: type-1 cannabinoid receptor and fatty acid amide hydrolase activity in male germ cells. Biol Reprod (2006) 75:82-9. doi:10.1095/biolreprod.106.051730

138. Cacciola G, Chioccarelli T, Ricci G, Meccariello R, Fasano S, Pierantoni R, et al. The endocannabinoid system in vertebrate male reproduction: a comparative overview. Mol Cell Endocrinol (2008) 286:S24-30. doi:10.1016/j.mce. 2008.01.004

139. Wenger T, Ledent C, Tramu G. The endogenous cannabinoid, anandamide, activates the hypothalamo-pituitary-adrenal axis in CB1 cannabinoid receptor knockout mice. Neuroendocrinology (2003) 78:294-300. doi:10.1159/ 000074882

140. Maccarrone M, Wenger T. Effects of cannabinoids on hypothalamic and reproductive function. Handb Exp Pharmacol (2005) 168:555-71. doi:10.1007/3540-26573-2_18

141. Oláh M, Milloh H, Wenger T. The role of endocannabinoids in the regulation of luteinizing hormone and prolactin release. Differences between the effects of AEA and 2AG. Mol Cell Endocrinol (2008) 286:S36-40. doi:10.1016/j.mce. 2008.01 .005

142. Grimaldi P, Orlando P, Di Siena S, Lolicato F, Petrosino S, Bisogno T, et al. The endocannabinoid system and pivotal role of the CB2 receptor in mouse spermatogenesis. Proc Natl Acad Sci U S A (2009) 106:11131-6. doi:10.1073/pnas.0812789106

143. Fasano S, Meccariello R, Cobellis G, Chianese R, Cacciola G, Chioccarelli T, et al. The endocannabinoid system: an ancient signaling involved in the control of male fertility. Ann N Y Acad Sci (2009) 1163:112-24. doi:10.1111/j.17496632.2009.04437.x

144. Cacciola G, Chioccarelli T, Mackie K, Meccariello R, Ledent C, Fasano S, et al. Expression of type-1 cannabinoid receptor during rat postnatal testicular development: possible involvement in adult Leydig cell differentiation. Biol Reprod (2008) 79:758-65. doi:10.1095/biolreprod.108.070128

145. Meccariello R, Chianese R, Cacciola G, Cobellis G, Pierantoni R, Fasano S. Type- 1 cannabinoid receptor expression in the frog, Rana esculenta, tissues: a possible involvement in the regulation of testicular activity. Mol Reprod Dev (2006) 73:551-8. doi:10.1002/mrd.20434

146. Wenger T, Ledent C, Csernus V, Gerendai I. The central cannabinoid receptor inactivation suppresses endocrine reproductive functions. Biochem Biophys Res Commun (2001) 284:363-8. doi:10.1006/bbrc.2001.4977

147. Chianese R, Ciaramella V, Fasano S, Pierantoni R, Meccariello R. Hypothalamus-pituitary axis: an obligatory target for endocannabinoids to 
inhibit steroidogenesis in frog testis. Gen Comp Endocrinol (2014). doi:10.1016/ j.ygcen.2014.02.010

148. Cobellis G, Ricci G, Cacciola G, Orlando P, Petrosino S, Cascio MG, et al. A gradient of 2-arachidonoylglycerol regulates mouse epididymal sperm cell start-up. Biol Reprod (2010) 82:451-8. doi:10.1095/biolreprod.109.079210

149. Ricci G, Cacciola G, Altucci L, Meccariello R, Pierantoni R, Fasano S, et al. Endocannabinoid control of sperm motility: the role of epididymis. Gen Comp Endocrinol (2007) 153:320-2. doi:10.1016/j.ygcen.2007.02.003

150. Cacciola G, Chioccarelli T, Altucci L, Viaggiano A, Fasano S, Pierantoni R, et al. Nuclear size as estrogen-responsive chromatin quality parameter of mouse spermatozoa. Gen Comp Endocrinol (2013) 193:201-9. doi:10.1016/j.ygcen. 2013.07.018

151. Cacciola G, Chioccarelli T, Fasano S, Pierantoni R, Cobellis G. Estrogens and spermiogenesis: new insights from type 1 cannabinoid receptor knockout mice. Int J Endocrinol (2013) 2013:501350. doi:10.1155/2013/501350

152. Lazaros LA, Xita NV, Kaponis AI, Zikopoulos KA, Plachouras NI, Georgiou IA. Estrogen receptor alpha and beta polymorphisms are associated with semen quality. J Androl (2010) 31:291-8. doi:10.2164/jandrol.109.007542

153. Lambard S, Galeraud-Denis I, Bouraïma H, Bourguiba S, Chocat A, Carreau S. Expression of aromatase in human ejaculated spermatozoa: a putative marker of motility. Mol Hum Reprod (2003) 9:117-24. doi:10.1093/molehr/gag020

154. Lambard S, Galeraud-Denis I, Martin G, Levy R, Chocat A, Carreau S. Analysis and significance of mRNA in human ejaculated sperm from normozoospermic donors: relationship to sperm motility and capacitation. Mol Hum Reprod (2004) 10:535-41. doi:10.1093/molehr/gah064

155. Lambard S, Galeraud-Denis I, Saunders PT, Carreau S. Human immature germ cells and ejaculated spermatozoa contain aromatase and oestrogen receptors. J Mol Endocrinol (2004) 32:279-89. doi:10.1677/jme.0.0320279

156. Said L, Saad A, Carreau S. Differential expression of mRNA aromatase in ejaculated spermatozoa from infertile men in relation to either asthenozoospermia or teratozoospermia. Andrologia (2014) 46:136-46. doi:10.1111/and.12058

157. Beck KJ, Herschel S, Hungershöfer R, Schwinger E. The effect of steroid hormones on motility and selective migration of X- and Y-bearing human spermatozoa. Fertil Steril (1976) 27:407-12.

158. Idaomar M, Guerin JF, Lornage J, Czyba JC. Stimulation of motility and energy metabolism of spermatozoa from asthenozoospermic patients by 17 betaestradiol. Arch Androl (1989) 22:197-202. doi:10.3109/01485018908986772

159. Mattingly KA, Ivanova MM, Riggs KA, Wickramasinghe NS, Barch MJ, Klinge CM. Estradiol stimulates transcription of nuclear respiratory factor-1 and increases mitochondrial biogenesis. Mol Endocrinol (2008) 22:609-22. doi:10.1210/me.2007-0029

160. Adeoya-Osiguwa SA, Markoulaki S, Pocock V, Milligan SR, Fraser LR. 17Betaestradiol and environmental estrogens significantly affect mammalian sperm function. Hum Reprod (2003) 18:100-7. doi:10.1093/humrep/deg037

161. Ded L, Dostalova P, Dorosh A, Dvorakova-Hortova K, Peknicova J. Effect of estrogens on boar sperm capacitation in vitro. Reprod Biol Endocrinol (2010) 8:87. doi:10.1186/1477-7827-8-87

162. Carani C, Qin K, Simoni M, Faustini-Fustini M, Serpente S, Boyd J, et al. Effect of testosterone and estradiol in a man with aromatase deficiency. $N$ Engl J Med (1997) 337:91-5. doi:10.1056/NEJM199707103370204

163. Herrmann BL, Saller B, Janssen OE, Gocke P, Bockisch A, Sperling H, et al. Impact of estrogen replacement therapy in a male with congenital aromatase deficiency caused by a novel mutation in the CYP19 gene. J Clin Endocrinol Metab (2002) 87:5476-84. doi:10.1210/jc.2002-020498

164. Maffei L, Murata Y, Rochira V, Tubert G, Aranda C, Vazquez M, et al. Dysmetabolic syndrome in a man with a novel mutation of the aromatase gene: effects of testosterone, alendronate, and estradiol treatment. J Clin Endocrinol Metab (2004) 89:61-70. doi:10.1210/jc.2003-030313

Conflict of Interest Statement: The authors declare that the research was conducted in the absence of any commercial or financial relationships that could be construed as a potential conflict of interest.

Received: 14 February 2014; accepted: 22 April 2014; published online: 08 May 2014. Citation: Meccariello R, Chianese R, Chioccarelli T, Ciaramella V, Fasano S, Pierantoni $R$ and Cobellis $G$ (2014) Intra-testicular signals regulate germ cell progression and production of qualitatively mature spermatozoa in vertebrates. Front. Endocrinol. 5:69. doi: 10.3389/fendo.2014.00069

This article was submitted to Experimental Endocrinology, a section of the journal Frontiers in Endocrinology.

Copyright $\odot 2014$ Meccariello, Chianese, Chioccarelli, Ciaramella, Fasano, Pierantoni and Cobellis. This is an open-access article distributed under the terms of the Creative Commons Attribution License (CC BY). The use, distribution or reproduction in other forums is permitted, provided the original author(s) or licensor are credited and that the original publication in this journal is cited, in accordance with accepted academic practice. No use, distribution or reproduction is permitted which does not comply with these terms. 